\title{
77. Triangular Biotitic Phlogopite in Basalt from Mutsuré-jima and its Chemical Composition.
}

\author{
By Shukusuké Kôzu and Shizuo Tsurumi. \\ Institute of Mineralogy, Petrology and Economic Geology, \\ Tohoku Imperial University, Sendai. \\ (Comm. by S. KôzU, M.I.A., June 12, 1933.)
}

The brown mica under present consideration occurs in the vesicles in basalt (Fig. 1), as stated in a previous account," but its genesis is of primary nature. The period of the crystallization of the mineral belongs to the later stage in the whole course of the crystallization of the basalt magma, followed by the formation of the acid plagioclase $(6 \% \mathrm{An})$ which forms the outermost zone of the plagioclase lath and is the latest component among the mineral ingredients forming the basalt.

The brown mica occurs in thin flakes with irregular outline, their diameters being $5 \mathrm{~mm}$ on the average. The flakes are aggregates of primitive triangular forms of the mica, piling onto each other according to a definite law (Figs. 2 and 3). The triangle is apparently regular, but the monoclinic plane of symmetry determined by the Laue spots is perpendicular to one of the edges of the triangle.

It has been known since early time that, by the gliding of planes

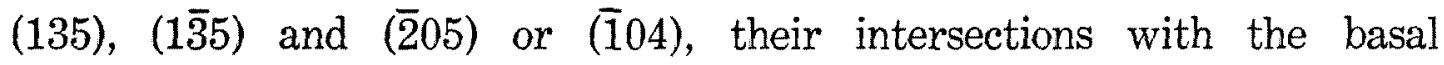
cleavage plane show an approximate regular triangle. In the recent studies made by Kikuchi, ${ }^{2)}$ Shinohara ${ }^{3)}$ and others, we can recognize prominent developments of the net planes corresponding to (131),

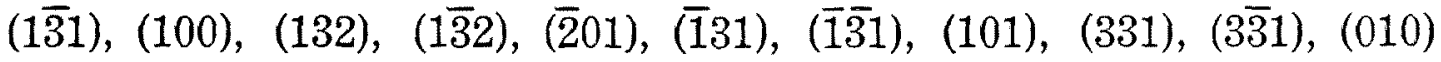
etc. by the analysis of muscovite using cathode rays. If any sets of the three planes mentioned above develop in keeping the relation of monoclinic symmetry, the results will be a triangular outline when they are cut by a basal cleavage plane.

Through the kindness of Mr. K. Fujimura, we were able to see a specimen of triangular phlogopite whose locality is a branch mine of Kapsan, Korea. Its photograph is reproduced here as seen in Fig. 4.

From the above statements, we may consider that the primitive form or "Urform" of the mica group, at least of some varieties of micas, may be triangular in the basal cleavage, not hexagonal.

Chemical composition:-The result of the chemical analysis made 
[Vol. 9,

from the fresh material of the Mutsurémica is given in Table I. The density of the material, measured by a Westphal balance, is 2.966 at $23^{\circ} \mathrm{C}$. The optical and thermal properties are as given in a previous paper.,

In order to compare the chemical compositions of the Mutsuré-mica with those of related micas, the composition of phlogopite from Rossie analyzed by Penfield and that of biotite from Miask analyzed by one (S. T.) of the present authors are given in parallel in Table $\mathrm{I}$. As is seen from Table, the chemical composition of the Mutsuré-mica possesses partly the nature of common biotite in that it contains more than $10 \%$ of $\mathrm{Fe}_{2} \mathrm{O}_{3}+\mathrm{FeO}$, while the high content of more than $19 \%$ of $\mathrm{MgO}$ is a characteristic of photograpite. So the chemical composition of the brown TABLE I.

\begin{tabular}{l|r|r|r}
\hline & \multicolumn{1}{|c|}{ I } & \multicolumn{1}{c|}{ II } & \multicolumn{1}{c}{ III } \\
\cline { 1 - 2 } $\mathrm{SiO}_{3}$ & 40.11 & 40.63 & 33.27 \\
$\mathrm{TiO}_{2}$ & 3.86 & 1.16 & 2.84 \\
$\mathrm{Al}_{2} \mathrm{O}_{3}$ & 9.89 & 13.04 & 12.78 \\
$\mathrm{Fe}_{2} \mathrm{O}_{3}$ & 3.20 & 1.12 & 11.84 \\
$\mathrm{FeO}$ & 7.40 & 7.62 & 18.05 \\
$\mathrm{MnO}$ & 0.11 & - & 0.93 \\
$\mathrm{MgO}$ & 19.99 & 21.47 & 6.51 \\
$\mathrm{CaO}$ & none & - & 0.14 \\
$\mathrm{Na}{ }_{2} \mathrm{O}$ & 2.61 & 0.57 & 0.74 \\
$\mathrm{~K}_{2} \mathrm{O}$ & 9.05 & 10.14 & 7.39 \\
$\mathrm{H}_{2} \mathrm{O}-$ & 1.08 & $-\overline{1}$ & 1.62 \\
$\mathrm{H}_{2} \mathrm{O}+$ & 2.46 & 2.47 & 4.24 \\
$\mathrm{P}_{2} \mathrm{O}_{5}$ & 0.09 & $-\overline{0}$ & n.d. \\
$\mathrm{F}$ & 0.29 & 4.00 & n.d. \\
$\mathrm{BaO}$ & n.d. & 0.04 & n.d. \\
\hline Total & 100.14 & 102.26 & 100.35 \\
\hline
\end{tabular}

I. Brown mica from Mutsuré-jima. Tsurumi anal.

II. Phlogopite from Rossie. Penfield anal.

III. Biotite from Miask. Tsurumi anal.

mica can be taken as an intermediate one between that of phlogopite and biotite. The refractive indices are also in the same relation. However, the especially low content of $\mathrm{Al}_{2} \mathrm{O}_{3}$, less than $10 \%$, is markedly different from any typical analyses of phlogopite and biotite already published. To ascertain this point more clearly, the chemical analysis of the mineral was repeated for essential oxides by two different persons in our Institute independently. The results not only agree well with each other within the limits of experimental error (Table II), but they compare well with the previous results given in Table I. So we can see clearly that the present mica is characterized by the low content of $\mathrm{Al}_{2} \mathrm{O}_{3}$.

Chemical Formula:-The determination of the chemical formula of the mica group is one of the most complex problems in mineralogical studies at present. J. Jakob, ${ }^{5)}$ W. Kunitz ${ }^{6)}$ and others made numerous chemical analyses of the mica group, and the former discussed his

TABLE II.

\begin{tabular}{l|r|r}
\hline & \multicolumn{1}{|c|}{$\mathrm{I}$} & \multicolumn{1}{|c}{ II } \\
\hline $\mathrm{SiO}_{2}$ & 40.02 & 40.14 \\
$\mathrm{Al}_{2} \mathrm{O}_{3}$ & 9.83 & 9.84 \\
$\mathrm{Fe}_{2} \mathrm{O}_{3}$ & 3.21 & 11.29 \\
$\mathrm{FeO}$ & 7.24 & 1.12 \\
$\mathrm{H}_{2} \mathrm{O}-$ & 0.94 \\
$\mathrm{TiO}_{2}$ & 3.91 & 3.84 \\
$\mathrm{MnO}$ & 0.12 & 0.10 \\
\hline
\end{tabular}

I. Tsurumi anal.

II. Yagi anal. 
results from the view point of the co-ordination theory. Ch. Mauguin ${ }^{7}$ found a prominent character in the chemical composition of the mica group from his $\mathrm{X}$-ray studies, that is, all kinds of mica contain 12 atoms of $\mathrm{O}+\mathrm{F}$ in their units of structure. This discovery is very important in the consideration of the crystal structure of the mineral. Adopting to this principle, L. Pauling ${ }^{8)}$ proposed two kinds of arrangement of atomic planes paralled to (001) for muscovite and phlogopite, by which the results obtained from chemical and X-ray analyses can be explained fairly well. Later Jackson and West ${ }^{9}$ published the structure of muscovite. However it seems that the question still remains unsolved for iron-rich micas such as biotite, lepidomelane etc.

If the formula of phlogopite $(\mathrm{OH})_{2} \mathrm{~K}\left(\mathrm{Mg}, \mathrm{Fe}^{\prime \prime}\right)_{3} \mathrm{AlSi}_{3} \mathrm{O}_{10}$ is taken for iron-rich mica, we will see that any results obtained by calculation for the number of molecules in the unit cell are not sufficient. The chief reason is undoubtedly the abundant presence of $\mathrm{Fe}$ instead of $\mathrm{Mg}$.

The Mutsuré mica is of a phlogopitic nature and the above formula is applicable with sufficient approximity as is seen below.

To facilitate comparison, the analysis of the mica given in Table I was recalculated to molecular proportions with $\mathrm{SiO}_{2}=300$. The results are $\mathrm{SiO}_{2}=300, \quad \mathrm{TiO}_{2}=21, \mathrm{Al}_{2} \mathrm{O}_{3}=43, \quad \mathrm{Fe}_{2} \mathrm{O}_{3}=18, \quad \mathrm{FeO}=46, \mathrm{MnO}=1$, $\mathrm{MgO}=225, \mathrm{Na}_{2} \mathrm{O}=19, \mathrm{~K}_{2} \mathrm{O}=43, \mathrm{H}_{2} \mathrm{O}=88, \mathrm{P}_{2} \mathrm{O}_{5}=1$ and $\mathrm{F}=14$. From these figures the phlogopite formula can be written as

$$
(\mathrm{OH}, \mathrm{F})_{183}(\mathrm{~K}, \mathrm{Na})_{124}\left(\mathrm{Mg}, \mathrm{Fe}^{\prime \prime}, \mathrm{Ti}\right)_{293}\left(\mathrm{Al}, \mathrm{Fe}^{\prime \prime \prime}\right)_{105} \mathrm{Si}_{300} \mathrm{O}_{1043} \text {, }
$$

which shows fairly good agreement with the theoretical phlogopite formula.

The cell dimentions of the Mutsuré-mica determined by us are

$$
a_{0}=5.29 \AA, b_{0}=9.27 \AA \text { and } d_{(001)}=20.05 \AA \text {. }
$$

So the volume of the unit cell is $982.16 \AA^{3}$. The molecular weight corresponding to the above formula is 448.6. Hence in the formula

$$
n=\frac{V \times \rho}{M \times 1.64 \times 10^{-24}}
$$

$n=3.95(\sim 4)$; that is, 4 molecules with the chemical formula given above are contained in a unit cell.

\section{References.}

1) S. Kôzu and B. Yoshiki: Proc. 9 (1933), 265-268.

2) S. Kikuchi : Jap. J. Phys., V, pp. 83 96, 1928.

3) K. Shinohara and (the late) K. Matukawa: Sci. Pap. I. P. C. P.; 21, pp. 21 15, 1932.

4) loc. cit.

5) J. Jakob: Z. Krist., Vols. 61, 62, 69, 70 and 72.

6) W. Kunitz: N. J. B. 50, pp. 365 412, 1924.

7) Ch. Mauguin : C. r., 185, 288, 1927; 186, 879 and 1131, 1928.

8) L. Pauling: Proc. Nat. Acad. Sci., 16, 123 129, 1930.

9) W. W. Jackson and J. West: Z. Krist., 67, pp. 211 227, 1931, and 85, 160 164, 1933. 


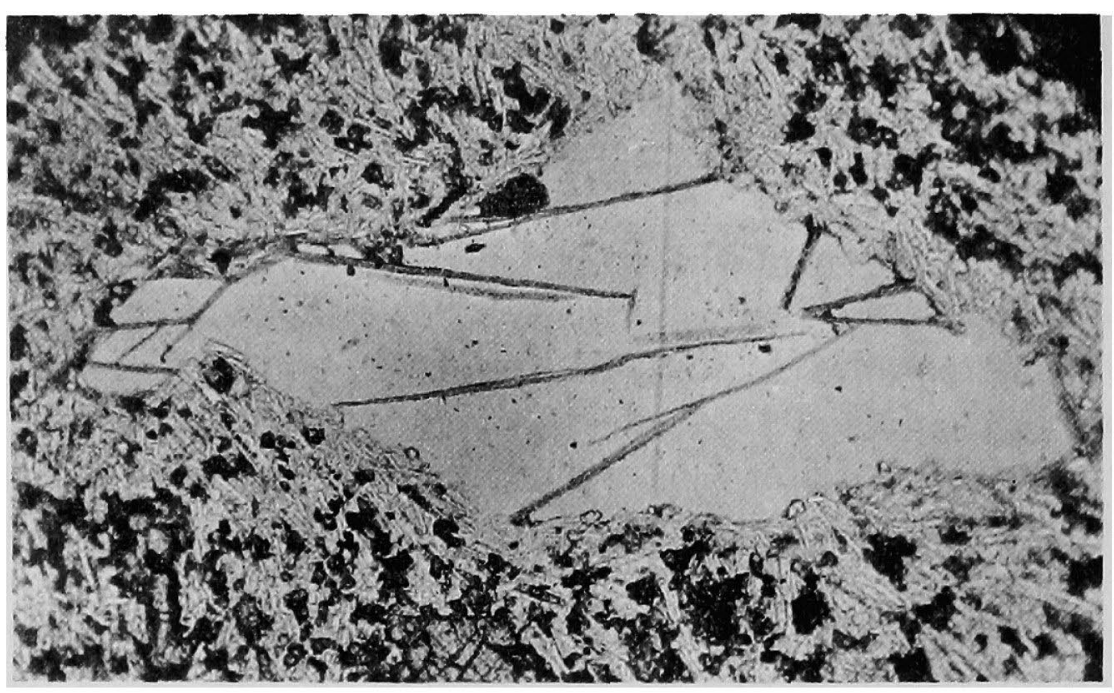

Fig. 1.

The brown micas traverse the vesicle in the basalt from Mutsuré-jima. $\times 30$.

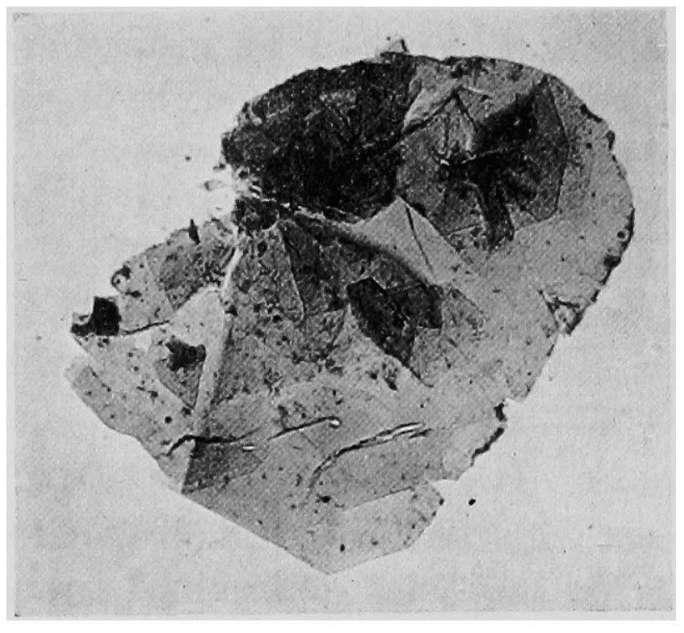

Fig. 2.

An aggregate of triangular brown mica in a definite law. $\times 9$.
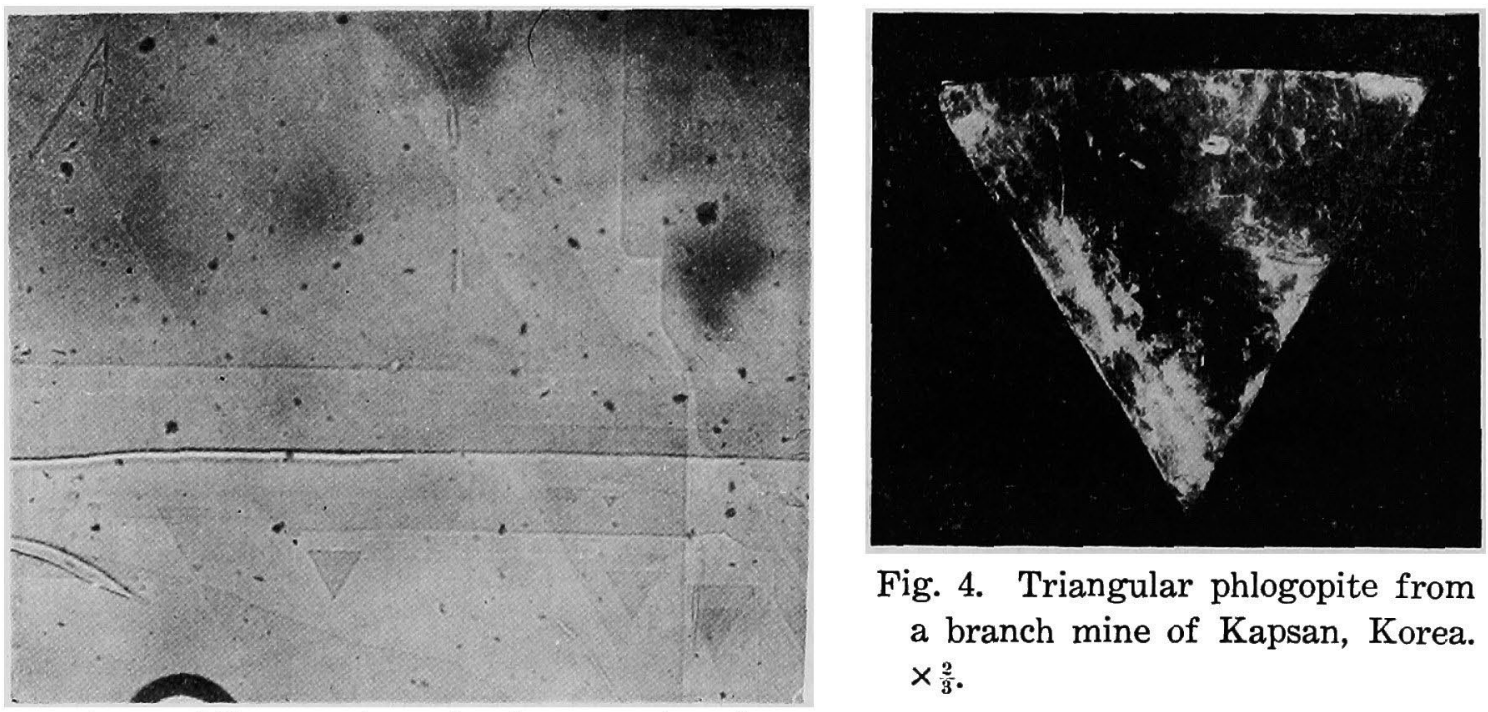

Fig. 4. Triangular phlogopite from a branch mine of Kapsan, Korea. $\times \frac{2}{3}$.

Fig. 3. Minute triangular brown micas in larger flakes of the same mineral. $\times 47$. 